\title{
PENENTUAN KOMBINASI KROMIUM-GAMBIR TERHADAP KEKUATAN TARIK PADA PROSES PENYAMAKAN KULIT IKAN TALANG-TALANG (QUEENFISH) DENGAN METODE TAGUCHI
}

\author{
Endang Sulistyaningsih, M. Syahri, Dyah Rachmawati Lucitasari \\ Program Studi Magister Teknik Industri Jurusan Teknik Industri \\ Fakultas Teknik Industri, Universitas Pembangunan Nasional "Veteran"Yogyakarta \\ Email: endangsulistya52@yahoo.com.
}

\begin{abstract}
ABSTRAK
Saat ini, kulit ikan masih sedikit jumlahnya sehingga jarang digunakan dalam industri penyamakan kulit. Kulit ikan talang-talang merupakan limbah buangan, sehingga dapat diolah menjadi kulit tersamak dan dapat dijadikan produk tas atau dompet, yang harus mempunyai kekuatan tarik yang baik, dimana tujuan dari penelitian ini adalah menentukan kombinasi kromium-gambir terhadap kekuatan tarik pada proses penyamakan kulit ikan talang-talang dengan metode Taguchi.

Dalam penelitian ini menggunakan faktor terkendali yaitu $\mathrm{Cr}_{2} \mathrm{O}_{3}$ (krome okside) 1,5\%, 2,5\%, 3,5\%, bahan gambir 6\%, 8\%, 10\%, waktu proses retanning 20 menit, 40 menit, 60 menit, minyak sulfat 10\%, 11\%, 12\%. Hasil pengolahan data menunjukkan bahwa kombinasi faktor dan level yang paling baik adalah faktor A (krome okside) level 3 yaitu 3,5\%, faktor B (bahan gambir) level 3 yaitu 10\%, faktor C (waktu proses retanning) level 2 yaitu 40 menit, faktor D (minyak sulfat) level 1 yaitu $10 \%$.

Penelitian ini dapat dikembangkan lebih lanjut dengan mengatur kembali faktor dan level kendali, menambahkan interaksi yang terjadi, lebih baik dilakukan dengan langkah studi kasus di lapangan, dan menambahkan analisis untuk menaikkan kualitas kulit ikan selain kekuatan tarik.
\end{abstract}

Kata kunci: Taguchi, kekuatan tarik, kulit ikan talang-talang, penyamakan kulit.

\section{ABSTRACT}

Currently, fish leather is still a few so it's rarely used on leather tanning industry. Queenfish leather is a waste that can be processed become tanned leather and become some product such as handbag or wallet, so it should has a good tensile strength, where the purpose of this research is to decide a combination of chromegambier to tensile strength on a tanning of Queenfish leather process by Taguchi method.

This research using controlled factor $\mathrm{Cr}_{2} \mathrm{O}_{3}$ (chrome oxide) 1,5\%, 2,5\%, 3,5\%, gambier 6\%, 8\%, 10\%, retanning process time 20 minutes, 40 minutes, 60 minutes, and sulfate oil 10\%, 11\%, 12\%. The result shows the best combination between factor and level are factor A (chrome oxide) level 3 is 3,5\%, factor B (gambier) level 3 is 10\%, factor C (retanning process time) level 2 is 40 minutes, and factor D (sulfate oil) level 1 is $10 \%$.

This research could be developed by rearranging the control factors and levels, adding the interaction, doing as case study on field, and adding the analyses to increase fish leather quality apart from tensile strength.

Keywords: Taguchi, tensile strength, Queenfish leather, tanning leather.

\section{PENDAHULUAN}

Di Indonesia industri penyamakan kulit yang menggunakan bahan mentah kulit yang berasal dari hewan darat sangatlah berkembang pesat dan menghasilkan produk jadi, mutunya tidak kalah dengan produk buatan luar negeri. Industri penyamakan kulit yang menggunakan bahan mentah kulit ikan masih sedikit jumlahnya. Pada saat ini kulit ikan yang digunakan dalam penyamakan masih terbatas pada jenis ikan hiu, pari, dan kakap. Ikan hiu termasuk jenis ikan besar, kulitnya tebal dan luas. Kulit ikan pari diambil kulitnya karena corak dari permukaan kulitnya, mempunyai ciri tersendiri yang tidak terdapat pada kulit jenis ikan lainnya.

Keuntungan dari penggunaan kulit ikan untuk penyamakan seperti halnya kulit hewan reptile adalah mempunyai ciri-ciri yang spesifik yang tidak di jumpai pada hewan darat, ciri-ciri tersebut memberikan nilai tambah tersendiri, dan bahan yang terbuat dari kulit ikan yang disamak sebagai produk yang sangat berharga. Dalam pemanfaatan hasil perikanan sebagai salah satu sumber pemasok industri penyamakan kulit masih menghadapi beberapa kendala dan masalah, terutama hasil perikanan merupakan komoditas yang cepat membusuk termasuk kulit. Komposisi kimia maupun struktur fisik kulit 
ikan berbeda dari kulit hewan darat, ikan lebih rentan terhadap kerusakan. Konsekuensinya untuk mendapatkan kulit yang dapat disamak harus diperoleh dari ikan yang kesegarannya prima. Penanganan ikan harus dilakukan dengan cara yang baik. Demikian juga kulit ikan yang dilepas dari tubuh ikan memerlukan penanganan yang baik dan diolah secepat mungkin.

Kelangkaan pemasokan kulit ikan ke industri penyamakan kulit, terutama pada sulitnya mendapatkan kulit ikan yang bermutu untuk penyamakan. Dengan dikembangkannya industri pengolahan kulit ikan diharapkan mempunyai dampak positif yang luas bagi kegiatan ekonomi di wilayah produsen. Kulit ikan talang-talang merupakan limbah kulit ikan bagi industri kuliner (masakan), karena kulit ikan talang-talang dapat menghambat bumbubumbu yang digunakan untuk memasak ikan pada waktu ikan di masak, sehingga bumbu tidak dapat masuk dan meresap ke dalam daging ikan yang berakibat rasa masakan menjadi kurang enak. Maka untuk mengatasi agar masakan daging ikan menjadi lebih enak dan bumbu bisa masuk ke dalam daging ikan, maka mengambil kulit ikan dulu dan dibuang. Di sini kulit ikan talang-talang hanya dibuang dan tidak dipakai, dan hanya sebagai limbah buangan. Diharapkan untuk dapat mengolah limbah kulit ikan talangtalang ini, agar bisa diolah dan disamak, serta bisa dipergunakan sebagai produk, seperti: tas, dompet, gantungan kunci, dan lain-lain.

Dengan melakukan kegiatan penyamakan kulit ini berarti menciptakan peluang yang baru dari bahan limbah, yang selama ini berdampak dapat mencemari lingkungan. Kegiatan industri ini bila berhasil dapat menyerap tenaga kerja, dan dapat meningkatkan pendapatan, bila produknya dapat dijual dan dipasarkan.

Dalam penelitian ini untuk menganalisis hasil data yang diperoleh, maka metode yang dipakai dengan menggunakan metode Taguchi. Metode Taguchi merupakan suatu metodologi baru dalam bidang teknik yang bertujuan untuk memperbaiki kualitas produk dan proses dalam waktu yang bersamaan menekan biaya dan sumber daya seminimal mungkin. Metode Taguchi berupaya mencapai sasaran itu dengan menjadikan produk atau proses "tidak sensitive" terhadap berbagai faktor seperti misalnya material, perlengkapan manufaktur, tenaga kerja manusia, dan kondisi-kondisi operasional. Metode Taguchi menjadikan produk atau proses bersifat kokoh (robust) terhadap faktor gangguan (noise), karenanya metode ini disebut juga sebagai perancangan kokoh (robust design).

Tujuan yang dilakukan dalam penelitian ini adalah menentukan kombinasi kromiumgambir terhadap kekuatan tarik pada proses penyamakan kulit ikan talang-talang (Queenfish) dengan metode Taguchi.

\section{METODOLOGI PENELITIAN}

Objek penelitian menggunakan ikan talang-talang, sebagai bahan baku. Bahan baku yang digunakan dalam penelitian ini adalah kulit ikan talang-talang, yang berasal dari pantai Depok masih dalam wilayah Yogyakarta. Studi lapangan dilakukan di pantai Depok, masih dalam wilayah kota Yogyakarta. Tempat penelitian dilakukan di laboratorium pengolahan limbah Politeknik ATK Yogyakarta dan di laboratorium pengujian fisis Politeknik ATK Yogyakarta.

Identifikasi dan penentuan faktor-faktor yang berpengaruh dan penetapan level faktor yaitu : Krome okside $\left(\mathrm{Cr}_{2} \mathrm{O}_{3}\right)$, Bahan gambir, Waktu proses retanning, dan Minyak sulfat. Karakteristik kualitas yang diterapkan adalah larger the better, dimana semakin besar maka semakin baik. Perhitungan derajat kebebasan bertujuan untuk mengetahui jumlah eksperimen yang dilakukan. Jumlah level dari masingmasing faktor adalah sebagai berikut :

Faktor $\mathrm{A}$ adalah $\mathrm{Cr}_{2} \mathrm{O}_{3}$ (krome okside) $=3$ level . Faktor $\mathrm{B}$ adalah bahan gambir $=3$ level.

Faktor $\mathrm{C}$ adalah waktu proses retanning $=3$ level.

Faktor D adalah minyak sulfat $=3$ level .

Pemilihan matriksnya adalah matriks ortogonal standar dengan 3 level dan Grafik Linear Standart.

Pelaksanaan eksperimen meliputi persiapan bahan baku, bahan kimia untuk proses penyamakan kulit, peralatan yang digunakan serta jalannya penelitian. Penelitian ini dimulai dari menentukan jenis kulit yang akan diteliti. Seperti yang sudah dijelaskan sebelumnya, kulit yang akan diteliti adalah kulit ikan talang-talang yang berasal dari pantai Depok Yogyakarta. Langkah selanjutnya melaksanakan penelitian di Laboratorium pengolahan limbah Politeknik ATK Yogyakarta, dan laboratorium pengujian fisis Politeknik ATK Yogyakarta dengan melakukan variasi penggunaan kromium dengan bahan kromosal B dan bahan penyamak ulang dengan bahan gambir, dan minyak sulfat, sehingga didapatkan kulit jadi yang baik. Proses 
berikutnya adalah melaksanakan pengujian kekuatan tarik.

Pengambilan data dilakukan dengan metode Taguchi, di mana karakteristik kualitas menurut nilai targetnya, karakteristiknya adalah larger-the-better, dan nilai targetnya sebesar mungkin (x), dimana semakin besar, maka semakin baik. Contoh: kuat tarik, kuat tekan, dan kekuatan las.

\section{HASIL DAN PEMBAHASAN}

Data yang digunakan dalam penelitian ini diperoleh dari hasil pengujian kekuatan tarik kulit ikan talang-talang dari pengujian 1 sampai dengan pengujian 9, yang dilakukan di laboratorium pengujian fisis Politeknik ATK Yogyakarta. Data hasil untuk masing-masing pengujian dapat dilihat pada Tabel 1. berikut :

Tabel 1. Data hasil pengujian kekuatan tarik kulit ikan talang-talang.

\begin{tabular}{|c|c|c|c|c|c|c|}
\hline Pengujian & $\begin{array}{c}\text { Force } \\
\text { @Peak } \\
(\mathrm{N})\end{array}$ & $\begin{array}{c}\text { Elong. } \\
\text { @ Peak } \\
(\mathrm{mm})\end{array}$ & $\begin{array}{c}\text { Area } \\
\left(\mathrm{mm}^{2}\right)\end{array}$ & $\begin{array}{c}\text { Tebal } \\
\text { Rata-rata } \\
(\mathrm{mm})\end{array}$ & $\begin{array}{c}\text { Elongation } \\
(\%)\end{array}$ & $\begin{array}{c}\text { Tensile } \\
\text { Strength } \\
\left(\mathrm{N} / \mathrm{mm}^{2}\right.\end{array}$ \\
\hline 1a & 27,459 & 3,843 & 5,500 & 0,55 & 7,686 & 4,992 \\
\hline 1b & 25,497 & 2,846 & 5,500 & 0,55 & 5,691 & 4,636 \\
\hline 1c & 37,265 & 6,866 & 8,000 & 0,8 & 13,732 & 4,658 \\
\hline 2a & 45,111 & 5,805 & 7,200 & 0,72 & 11,609 & 6,265 \\
\hline 2b & 37,265 & 4,791 & 6,500 & 0,65 & 9,582 & 5,733 \\
\hline 2c & 49,033 & 11,631 & 9,700 & 0,97 & 23,263 & 5,055 \\
\hline 3a & 45,111 & 8,824 & 6,000 & 0,6 & 17,648 & 7,518 \\
\hline 3b & 60,801 & 10,973 & 9,000 & 0,9 & 21,945 & 6,756 \\
\hline 3c & 45,111 & 7,670 & 6,700 & 0,67 & 15,339 & 6,733 \\
\hline 4a & 76,492 & 9,267 & 9,200 & 0,92 & 18,534 & 8,314 \\
\hline 4b & 50,995 & 6,169 & 6,300 & 0,633 & 12,338 & 8,094 \\
\hline 4c & 88,260 & 9,973 & 11,000 & 1,1 & 19,947 & 8,024 \\
\hline 5a & 96,974 & 7,111 & 12,000 & 1,2 & 14,220 & 8,041 \\
\hline 5b & 90,221 & 9,626 & 9,500 & 0,95 & 19,252 & 9,497 \\
\hline 5c & 80,415 & 10,614 & 8,300 & 0,83 & 21,228 & 9,688 \\
\hline 6a & 78,453 & 9,452 & 7,200 & 0,72 & 18,904 & 10,896 \\
\hline 6b & 92,183 & 9,986 & 9,000 & 0,9 & 19,973 & 10,243 \\
\hline 6c & 96,105 & 9,867 & 9,300 & 0,933 & 19,735 & 10,334 \\
\hline $7 \mathrm{a}$ & 60,801 & 9,626 & 4,300 & 0,43 & 19,252 & 14,140 \\
\hline 7b & 98,066 & 17,030 & 7,300 & 0,73 & 34,060 & 13,434 \\
\hline $7 \mathrm{c}$ & 92,183 & 12,166 & 7,200 & 0,72 & 24,332 & 12,803 \\
\hline 8a & 158,868 & 9,223 & 7,700 & 0,77 & 18,446 & 20,632 \\
\hline 8b & 98,066 & 9,809 & 6,500 & 0,65 & 19,618 & 15,087 \\
\hline 8c & 105,912 & 11,604 & 7,000 & 0,7 & 23,208 & 15,130 \\
\hline 9a & 176,520 & 13,192 & 7,000 & 0,7 & 26,385 & 25,217 \\
\hline 9b & 237,321 & 14,135 & 10,300 & 1,033 & 28,270 & 23,041 \\
\hline 9c & 168,674 & 13,760 & 7,300 & 0,73 & 27,519 & 23,106 \\
\hline & & & & & & \\
\hline
\end{tabular}

Data hasil pengujian dan pengolahan data pengujian kekuatan tarik kulit ikan talang-talang untuk masing-masing pengujian, dapat dilihat pada Tabel 2. berikut :

Tabel 2. Data hasil pengujian kekuatan tarik kulit ikan talang-talang. 


\begin{tabular}{|c|c|c|c|c|c|c|c|c|c|}
\hline \multicolumn{10}{|c|}{ Matriks Ortogonal $\mathrm{L}_{9}\left(3^{4}\right)$} \\
\hline \multirow{2}{*}{$\begin{array}{l}\text { Pengujian / } \\
\text { Eksperimen }\end{array}$} & \multicolumn{4}{|c|}{ Faktor } & \multicolumn{3}{|c|}{ Replikasi ( $\left.\mathrm{N} / \mathrm{mm}^{2}\right)$} & \multirow[t]{2}{*}{ Jumlah } & \multirow{2}{*}{$\begin{array}{c}\text { Rata- } \\
\text { rata }\end{array}$} \\
\hline & A & B & $\mathrm{C}$ & $\mathrm{D}$ & 1 & 2 & 3 & & \\
\hline 1 & 1 & 1 & 1 & 1 & 4,992 & 4,636 & 4,658 & 14,286 & 4,762 \\
\hline 2 & 1 & 2 & 2 & 2 & 6,265 & 5,733 & 5,055 & 17,053 & 5,684 \\
\hline 3 & 1 & 3 & 3 & 3 & 7,518 & 6,756 & 6,733 & 21,007 & 7,002 \\
\hline 4 & 2 & 1 & 2 & 2 & 8,314 & 8,094 & 8,024 & 24,432 & 8,144 \\
\hline 5 & 2 & 2 & 3 & 1 & 8,041 & 9,497 & 9,688 & 27,226 & 9,075 \\
\hline 6 & 2 & 3 & 1 & 2 & 10,896 & 10,243 & 10,334 & 31,473 & 10,491 \\
\hline 7 & 3 & 1 & 3 & 2 & 14,140 & 13,434 & 12,803 & 40,377 & 13,459 \\
\hline 8 & 3 & 2 & 1 & 3 & 20,632 & 15,087 & 15,130 & 50,849 & 16,949 \\
\hline 9 & 3 & 3 & 2 & 1 & 25,217 & 23,041 & 23,106 & 71,364 & 23,788 \\
\hline
\end{tabular}

Untuk mengetahui pengaruh level dari faktor terhadap rata-rata kekuatan tarik yang dilakukan analisa menggunakan metode Taguchi, tahapan pengolahan data dilakukan dengan cara sebagai berikut:

Pengaruh level dari faktor terhadap rata-rata kekuatan tarik kulit ikan talang-talang. Untuk mengidentifikasi pengaruh level dari faktor terhadap rata-rata kekuatan tarik kulit ikan talang-talang, maka dilakukan pengolahan data kekuatan tarik untuk setiap faktor.

Nilai rata-rata terbesar digunakan sebagai rancangan usulan yang sesuai dengan karakteristik mutu larger the better. Hasil perhitungan Tabel respon kekuatan tarik kulit ikan talang-talang, terdapat pada Tabel 3. berikut :

Tabel 3. Respon rata-rata nilai kekuatan tarik dari pengaruh faktor.

\begin{tabular}{|c|c|c|c|c|}
\hline Faktor / level & A & B & C & D \\
\hline Level 1 & 5,816 & 8,788 & 10,734 & 12,542 \\
\hline Level 2 & 9,237 & 10,569 & 12,539 & 9,445 \\
\hline Level 3 & 18,065 & 13,760 & 9,845 & 11,976 \\
\hline Selisih & 12,249 & 4,972 & 2,694 & 3,097 \\
\hline Ranking & 1 & 2 & 4 & 3 \\
\hline
\end{tabular}

Pemilihan ranking dilakukan dengan cara mengurangi selisih level pada faktor tertinggi dikurangi level terendah, kemudian diurutkan berdasarkan selisih terbesar ke terkecil. Berdasarkan hasil perhitungan respon rata-rata kekuatan tarik dari pengaruh faktor nilai tersebut dituangkan ke dalam grafik. Grafik respon ratarata kekuatan tarik dari pengaruh faktor dapat dilihat pada Gambar 1. berikut: 


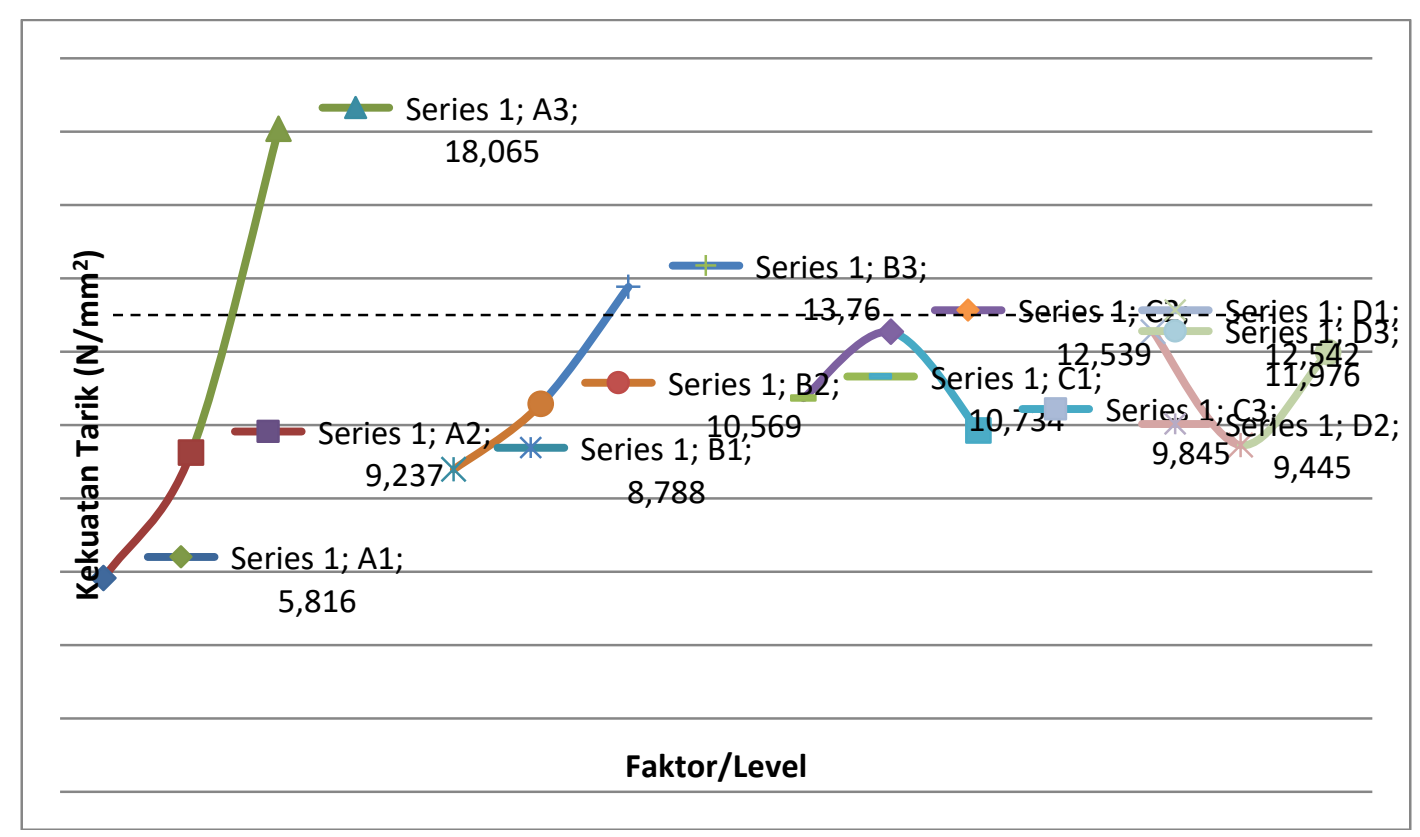

\section{Gambar 1. Grafik respon dari pengaruh faktor}

Dalam penelitian ini di pilih 4 faktor penting dari Tabel respon rata-rata kekuatan tarik dari pengaruh faktor, sehingga dari grafik kombinasi level faktor yang

menghasilkan nilai kekuatan tarik yang paling besar yaitu : pada Faktor A3, B3, D1, dan C2.

$\mathrm{A} 3$ = krome okside $\mathrm{Cr}_{2} \mathrm{O}_{3} 3,5 \%$.

$\mathrm{B} 3$ = bahan gambir $10 \%$.

$\mathrm{C} 2$ = waktu proses retanning 40 menit.

$\mathrm{D} 1=$ minyak sulfat $10 \%$.

Analisis varians rata-rata kekuatan tarik kulit ikan talang-talang.

Hasil perhitungan jumlah kuadrat dan rata-rata jumlah kuadrat untuk setiap faktor selengkapnya dapat dilihat pada Tabel 4. berikut :

Tabel 4. Analisis varians rata-rata kekuatan tarik

\begin{tabular}{|c|c|r|r|}
\hline Sumber & V & SS & MS \\
\hline A & 2 & 239,675 & 119,637 \\
\hline B & 2 & 38,075 & 19,037 \\
\hline C & 2 & 11,305 & 5,653 \\
\hline D & 2 & 18,696 & 9,348 \\
\hline Error & 6 & 128,703 & 21,451 \\
\hline Total & 14 & 436,454 & \multicolumn{1}{|c}{} \\
\cline { 1 - 2 } & &
\end{tabular}

Jumlah kuadrat terkecil dari faktor yang tidak signifikan yaitu faktor C dan D. Perhitungan penggabungan pertama dilakukan dengan menggabungkan faktor $\mathrm{C}$ ke dalam variansi error, yaitu :

$\mathrm{Ve}=\mathrm{Ve}+\mathrm{Vc}=6+2=8$

$\mathrm{SSe}=\mathrm{SSe}+\mathrm{SSc}=128,703+11,305=140$, 008

$\mathrm{MSe}=\frac{S S e}{V e}=\frac{140,008}{8}=17,501$

Setelah dilakukan hasil rata-rata jumlah kuadrat error (MSe) yang digabungkan dengan faktor C, selanjutnya dilakukan perhitungan F-rasio. Perhitungan untuk faktor A, yaitu :

F-rasio $_{\mathrm{A}}=\frac{M S A}{M S e}=\frac{119,837}{17,501}=6,847$

F-rasio ${ }_{\mathrm{B}}=\frac{M S B}{M S e}=\frac{19,037}{17,501}=1,088$

F-rasio $=\frac{M S D}{M S e}=\frac{9,348}{17,501}=0,534$

Hasil penggabungan tersebut menyebabkan struktur Tabel analisis varians berubah seperti Tabel 5. berikut : 
Tabel 5. Analisis varians penggabungan I

\begin{tabular}{|c|c|c|c|c|}
\hline Sumber & V & SS & MS & F-rasio \\
\hline A & 2 & 239,675 & 119,837 & 6,847 \\
\hline B & 2 & 38,075 & 19,037 & 1,088 \\
\hline C & \multicolumn{3}{|c|}{ Pooling } \\
\hline D & 2 & 18,696 & 9,348 & 0,534 \\
\hline Error & 8 & 128,703 & 21,451 & - \\
\hline Total & 14 & 436,454 & - & - \\
\hline
\end{tabular}

Pengujian hipotesis dan kesimpulan yang diperoleh dari Tabel 5. setelah dilakukan pooling terhadap faktor $\mathrm{C}$ adalah sebagai berikut :

$\mathrm{H}_{\mathrm{O}}=$ Tidak ada pengaruh faktor A terhadap kekuatan tarik kulit ikan talang-Talang.

$\mathrm{H}_{\mathrm{O}}=$ Tidak ada pengaruh faktor B terhadap kekuatan tarik kulit ikan talang-Talang.

Kesimpulan F hitung $=1,088<\mathrm{F}_{(0,10 ; 2,8)}=4,46$; maka $\mathrm{H}_{\mathrm{o}}$ diterima, artinya tidak ada pengaruh penggunaan proses retanning dengan bahan gambir terhadap kekuatan tarik kulit ikan talangtalang.

$\mathrm{H}_{\mathrm{O}}=$ Tidak ada pengaruh faktor $\mathrm{D}$ terhadap kekuatan tarik kulit ikan talang-Talang.

$\mathrm{H} 1$ = Ada pengaruh faktor $\mathrm{D}$ terhadap kekuatan tarik kulit ikan talang-talang.

Kesimpulan F hitung $=0,534<\mathrm{F}_{(0,10 ; 2,8)}=4,46$; maka $\mathrm{H}_{\mathrm{o}}$ diterima, artinya tidak ada pengaruh penggunaan minyak sulfat pada proses penyamakan kulit terhadap kekuatan tarik kulit ikan talang-talang.

Perhitungan selanjutnya yaitu merupakan perhitungan analisis varians kekuatan tarik dengan pooling kedua yaitu pada faktor D.
H1 = Ada pengaruh faktor A terhadap kekuatan tarik kulit ikan talang-talang.

Kesimpulan F hitung $=6,847>\mathrm{F}_{(0,10 ; 2,8)}=4,46$; maka $\mathrm{H}_{\mathrm{o}}$ ditolak, artinya ada pengaruh penggunaan kromium terhadap kekuatan tarik kulit ikan talang-talang.

$\mathrm{H} 1$ = Ada pengaruh faktor $\mathrm{B}$ terhadap kekuatan tarik kulit ikan talang-talang.

Perhitungan penggabungan kedua dilakukan dengan menggabungkan faktor $\mathrm{D}$ ke dalam variansi error, yaitu :

$\mathrm{Ve}=\mathrm{Ve}+\mathrm{V}_{\mathrm{D}}=8+2=10$

$\mathrm{SSe}=\mathrm{SSe}+\mathrm{SS}_{\mathrm{D}}=128,703+18,696=147,399$

$\mathrm{MSe}=\frac{S S e}{V e}=\frac{147,399}{10}=14,7399$

Setelah dilakukan hasil rata-rata jumlah kuadrat error yang digabungkan dengan faktor D, selanjutnya dilakukan perhitungan $\mathrm{F}$ rasio. Perhitungan untuk faktor A, yaitu :

F-rasio $_{\mathrm{A}}=\frac{M S A}{M S e}=\frac{119,837}{14,7399}=8,130$

$\mathrm{F}$ rasio $_{\mathrm{B}}=\frac{M S B}{M S e}=\frac{19,037}{14,7399}=1,292$

Hasil penggabungan tersebut menyebabkan struktur Tabel analisis varians berubah seperti Tabel 6. berikut :

Tabel 6. Analisis varians penggabungan II

\begin{tabular}{|c|c|r|c|c|}
\hline Sumber & V & \multicolumn{1}{c|}{ SS } & MS & F-rasio \\
\hline A & 2 & 239,675 & 119,837 & 8,130 \\
\hline B & 2 & 38,075 & 19,037 & 1,292 \\
\hline D & \multicolumn{5}{|c|}{ Pooling } \\
\hline Error & 10 & 147,399 & 14,7399 & - \\
\hline Total & 14 & 425,149 & - & - \\
\hline
\end{tabular}

Setelah dilakukan pooling terhadap faktor D adalah sebagai berikut :

$\mathrm{H}_{\mathrm{O}}=$ Tidak ada pengaruh faktor A terhadap kekuatan tarik kulit ikan talangTalang.

$\mathrm{H} 1$ = Ada pengaruh faktor A terhadap kekuatan tarik kulit ikan talang-talang.

Kesimpulan F hitung $=8,130>\mathrm{F}_{(0,10 ; 2,10)}=4,10$; maka $\mathrm{H}_{\mathrm{o}}$ ditolak, artinya ada pengaruh penggunaan kromium terhadap kekuatan tarik kulit ikan talang-talang.

$\mathrm{H}_{\mathrm{O}} \quad=$ Tidak ada pengaruh faktor $\mathrm{B}$ terhadap kekuatan tarik kulit ikan talangTalang.

$\mathrm{H} 1$ = Ada pengaruh faktor $\mathrm{B}$ terhadap kekuatan tarik kulit ikan talang-talang.

Kesimpulan F hitung $=1,292<\mathrm{F}_{(0,10 ; 2,10)}=4,10$; maka $\mathrm{H}_{\mathrm{o}}$ diterima, artinya tidak ada pengaruh 
penggunaan proses retanning dengan bahan gambir terhadap kekuatan tarik kulit ikan talangtalang.

Perhitungan selanjutnya yaitu merupakan perhitungan analisis varians kekuatan tarik dengan pooling ketiga yaitu pada faktor B. Perhitungan penggabungan ketiga dilakukan dengan menggabungkan faktor $\mathrm{B}$ ke dalam variansi error, yaitu:

$$
\begin{aligned}
\mathrm{Ve} & =\mathrm{Ve}+\mathrm{V}_{\mathrm{B}}=10+2=12 \\
\mathrm{SSe} & =\mathrm{SSe}+\mathrm{SS}_{\mathrm{B}}=147,399+38,075 \\
& =185,474
\end{aligned}
$$

MSe $=\frac{S S e}{V e}=\frac{185,474}{12}=15,456$

Setelah dilakukan hasil rata-rata jumlah kuadrat error (MSe) yang digabungkan dengan faktor $\mathrm{B}$, selanjutnya dilakukan perhitungan $\mathrm{F}$ rasio. Perhitungan untuk faktor A, yaitu :

$\mathrm{F}^{- \text {rasio }_{\mathrm{A}}}=\frac{M S A}{M S e}=\frac{119,837}{15,456}=7,753$

Hasil penggabungan menyebabkan struktur Tabel analisis varians berubah seperti Tabel 7. berikut :

Tabel 7. Analisis varians penggabungan III

\begin{tabular}{|c|c|c|c|c|}
\hline Sumber & V & SS & MS & F-rasio \\
\hline A & 2 & 239,675 & 119,837 & 7,753 \\
\hline B & \multicolumn{5}{|c|}{ Pooling } \\
\hline Error & 12 & 185,474 & 15,456 & - \\
\hline Total & 14 & 425,149 & - & - \\
\hline
\end{tabular}

Dari hasil Pengujian hipotesis dan kesimpulan, setelah dilakukan pooling terhadap faktor B adalah sebagai berikut:

$\mathrm{H}_{\mathrm{O}}=$ Tidak ada pengaruh faktor A terhadap kekuatan tarik kulit ikan talang-Talang.

$\mathrm{H} 1 \mathrm{~A}$ Ada pengaruh faktor $\mathrm{A}$ terhadap kekuatan tarik kulit ikan talang-talang.

Kesimpulan $F$ hitung $=7,753>F_{(0,10 ; 2,12)}=3,89$ ; maka $\mathrm{H}_{\mathrm{o}}$ ditolak, artinya ada pengaruh penggunaan kromium terhadap kekuatan tarik kulit ikan talang-talang.

Sebelum melakukan perhitungan persen kontribusi, dilakukan perhitungan jumlah kuadrat deviasi dari faktor A yang dihitung menggunakan persamaan:

SS'A = SS faktor $-($ Ve $x$ V faktor $)$

$=239,675-(15,456 \times 2)=239,675-$ $30,912=208,763$

Setelah dilakukan perhitungan SS' langkah selanjutnya yaitu menentukan persentase jumlah kuadrat dari faktor A. Perhitungan untuk persen kontribusi faktor A yaitu :

$\mathrm{P}_{\mathrm{A}}=\frac{\mathrm{SS}^{\prime} \text { 'aktor }}{\text { SST }}=\frac{208,763}{425,149} \times 100 \%=49,103 \%$

Hasil perhitungan persen kontribusi dapat dilihat pada Tabel 8 . berikut :

Tabel 8. Hasil perhitungan persen kontribusi

\begin{tabular}{|c|c|c|c|c|c|}
\hline Sumber & V & SS & MS & F-rasio & $\mathrm{P}(\%)$ \\
\hline A & 2 & 239,675 & 119,837 & 7,753 & 49,103 \\
\hline Error & 12 & 185,474 & 15,456 & - & - \\
\hline Total & 14 & 425,149 & - & - & - \\
\hline
\end{tabular}

Perhitungan kontribusi faktor, menunjukkan bahwa hanya faktor A (krome okside $/ \mathrm{Cr}_{2} \mathrm{O}_{3}$ ) yang memberikan kontribusi terhadap kekuatan tarik kulit ikan talang-talang, yaitu sebesar 49,103\%.

Prediksi rata-rata pengujian kekuatan tarik kulit ikan talang-talang ( $\mu$ prediksi) pada kondisi optimum adalah: $\mu$ prediksi $=\overline{\mathrm{y}}+\left(\mathrm{A}_{3}-\overline{\mathrm{y}}\right)+\left(\mathrm{B}_{3}-\overline{\mathrm{y}}\right)-\left(\overline{\mathrm{C}}_{2}\right.$ $-\overline{\mathrm{y}})$

$$
=\overline{\mathrm{A}}_{3}+\overline{\mathrm{B}}_{3}+\overline{\mathrm{C}}_{2}-2 \overline{\mathrm{y}}
$$

$$
\begin{aligned}
= & 18,065+13,760+12,542- \\
& 2(11,039) \\
= & 44,367-22,078 \\
= & 22,289 \mathrm{~N} / \mathrm{mm}^{2}
\end{aligned}
$$

Kekuatan tarik adalah besarnya gaya maksimal yang diperlukan untuk menarik kulit sampai putus, dinyatakan dalam Newton $/ \mathrm{mm}^{2}$. Kekuatan tarik merupakan salah satu parameter penting yang menjadi patokan terhadap kualitas dari kulit tersamak karena dapat menggambarkan kuatnya ikatan antara serat kolagen penyusun kulit dengan zat penyamak. 
Proses penyamakan yang baik akan menghasilkan kulit dengan kekuatan tarik yang tinggi. Kekuatan tarik dalam aplikasinya sangat penting terutama dalam industri yang menggunakan bahan baku kulit. Kekuatan tarik kulit yang kurang dari persyaratan akan menyebabkan kulit mudah pecah atau retak. Pengujian kekuatan tarik pada umumnya dilakukan untuk mengetahui sifat-sifat mekanis dari suatu material.

Ketebalan kulit memegang peranan penting yang berpengaruh terhadap kekuatan tarik, semakin tebal kulit maka akan semakin besar pula kekuatan tariknya. Ketebalan akan mempengaruhi kestabilan kulit, dimana kestabilan kulit ini dipengaruhi oleh ikatan silang yang terbentuk antara bahan penyamak dan protein kulit.

Kekuatan tarik suatu kulit tersamak dipengaruhi oleh beberapa faktor diantaranya proses peminyakan kulit, ketebalan kulit, struktur kulit, dan besarnya konsentrasi krom yang digunakan. Kulit yang terlalu tipis atau terlalu tebal akan menghasilkan uji tarik yang kurang bagus. Struktur kulit yang kurang bagus, dengan kandungan kolagen yang kurang akan menyebabkan penyerapan krom kurang sempurna sehingga mutu uji tarik yang dihasilkan kurang maksimal. Proses peminyakan bertujuan menjadikan serat-serat kulit menjadi lembut dan fleksibel saat dipegang. Semakin tinggi konsentrasi krom pengikatan minyak akan semakin tinggi pula (Hidayati, 2015).

Dari hasil penelitian didapatkan pada krome okside (faktor A) pada level $1(1,5 \%)$ diperoleh $5,816 \mathrm{~N} / \mathrm{mm}^{2}$, level $2(2,5 \%)$ diperoleh $9,237 \mathrm{~N} / \mathrm{mm}^{2}$, level $3(3,5 \%)$ diperoleh $18,065 \mathrm{~N} / \mathrm{mm}^{2}$, dari hasil penelitian ini dapat memberikan bukti bahwa semakin banyak bahan penyamak (krome okside) yang terikat pada kulit menyebabkan kekuatan tarik dari kulit samak akan semakin tinggi. Konsentrasi bahan penyamak yang tepat dapat menghasilkan kualitas kekuatan fisik yang baik. Konsentrasi yang kurang tepat akan menyebabkan kekuatan fisik kulit menurun.

Dari hasil penelitian didapatkan pada bahan gambir (faktor B) pada level 1 (6\%) diperoleh $8,788 \mathrm{~N} / \mathrm{mm}^{2}$, level $2(8 \%)$ diperoleh $10,569 \mathrm{~N} / \mathrm{mm}^{2}$, level $3(10 \%)$ diperoleh 13,760 $\mathrm{N} / \mathrm{mm}^{2}$, dari hasil penelitian ini dapat memberikan bukti bahwa semakin banyak bahan penyamak (bahan gambir) yang terikat pada kulit menyebabkan kekuatan tarik dari kulit samak akan semakin tinggi. Konsentrasi bahan penyamak yang tepat dapat menghasilkan kualitas kekuatan fisik yang baik. Konsentrasi yang kurang tepat akan menyebabkan kekuatan fisik kulit menurun.

Dari hasil penelitian didapatkan pada waktu proses retanning (faktor C) pada level 1 (20 menit) diperoleh $10,734 \mathrm{~N} / \mathrm{mm}^{2}$, level 2 (40 menit) diperoleh $12,539 \mathrm{~N} / \mathrm{mm}^{2}$, level $3(60$ menit) diperoleh $9,845 \mathrm{~N} / \mathrm{mm}^{2}$, dari hasil penelitian ini dapat memberikan bukti bahwa waktu yang tepat untuk dipergunakan proses retanning adalah 40 menit, karena waktu untuk proses retanning diatur sesingkat mungkin. Hal ini untuk menghindari kerusakan kulit yang diakibatkan oleh gerakan mekanik kulit dalam drum atau perlakuan dalam peremasan kulit. Indikator (tanda) waktu proses retanning dianggap cukup apabila larutan retanning sudah tak berwarna (larutan bening).

Dari hasil penelitian didapatkan pada minyak sulfat (penggunaan /pemberian minyak sulfat (faktor D) pada level 1 (10\%) diperoleh $12,542 \mathrm{~N} / \mathrm{mm}^{2}$, level $2(11 \%)$ diperoleh 9,445 $\mathrm{N} / \mathrm{mm}^{2}$, level 3 (12\%) diperoleh 11,976 $\mathrm{N} / \mathrm{mm}^{2}$; dari hasil penelitian ini dapat memberikan bukti bahwa minyak sulfat yang digunakan untuk proses peminyakan kulit (fatliquoring), mempunyai tujuan mengubah sifat kulit agar lebih lemas dan tahan terhadap perlakuan fisis dan khemis (terhadap air). Kelemasan dimungkinkan karena antar serat kolagen terjadi pelinciran oleh adanya minyak, sehingga sekaligus mengakibatkan kulit bersifat hydrofob (tahan terhadap air). Jumlah minyak sulfat yang terlalu banyak terserap ke dalam kulit dapat berakibat :

1. Kulit akan sangat licin bila dijahit (untuk dijadikan produk).

2. Kulit susah dilem apabila mendapatkan perlakuan pengeleman.

3. Kulit akan mudah ditumbuhi jamur, karena kondisi kulit sangat lembab.

Penyamakan kombinasi kromiumgambir, bisa diterapkan dan dilakukan pada kulit ikan talang-talang. Limbah kulit ikan talang-talang dapat diolah menjadi kulit tersamak, menggunakan bahan penyamak kombinasi kromium-gambir.Pengaruh faktor yang signifikan terhadap kekuatan tarik kulit ikan talang-talang adalah faktor A3, B3, D1, C2.

\section{KESIMPULAN DAN SARAN}

Kesimpulan 
Hasil dari menentukan kombinasi kromium-gambir terhadap kekuatan tarik pada proses penyamakan kulit ikan talang-talang dengan metode Taguchi adalah :

1. $\mathrm{Cr}_{2} \mathrm{O}_{3}$ (krome oxide) sebesar 3,5\%;

2. Bahan gambir sebesar $10 \%$;

3. Waktu proses retanning adalah 40 menit;

4. Minyak sulfat sebanyak $10 \%$.

\section{Saran}

1. Mengatur kembali faktor dan level kendali yang berpengaruh terhadap kekuatan tarik kulit ikan talang-talang, serta menambahkan interaksi yang terjadi.

2. Sebaiknya penelitian ini dilakukan studi kasus di lapangan.

3. Menambahkan parameter yang lain, selain kekuatan tarik.

\section{DAFTAR PUSTAKA}

Anonim. 2011. Penyamakan Krom.

Anonim. 2011. Talang-Talang.

Badan Standardisasi Nasional.1990. Cara Uji Kekuatan Tarik dan Kemuluran Kulit. SNI 06-1795-1990.

Badan Standardisasi Nasional. 1999. Kulit Ikan Pari untuk Barang Kulit. SNI 06-61211999.

Badan Standardisasi Nasional. 2012. Kulit Metoda Uji Fisis dan Mekanis Penentuan Kuat Tarik dan Kemuluran. SNI ISO 3376:2012.

Badan Standardisasi Nasional.2012. Kulit Bagian Atas Alas Kaki- Kulit Kambing.SNI 0253-2009.

Badan Standardisasi Nasional.1989. Kulit Glace Kambing, Mutu Dan Cara Uji. SNI 06-0253-1989.

Susanto, H.B. 2013. Penentuan Kombinasi Bahan Penyamak Nabati dan Minyak terhadap Mutu Fisik Kulit Jaket dengan Perancangan Eksperimen Di Balai Besar Kulit Karet dan Plastik Yogyakarta.

Sriwiyati, T. dan Titik A. 2017. Petunjuk Praktikum Pengujian Organoleptis Dan Fisis Kulit. Politeknik ATK Yogyakarta.

Wazah. 1993. Teknologi Kulit. Akademi Teknologi Kulit Yogyakarta.

Wahyudi, D. dan Gan S. S.2015. Optimasi proses injeksi dengan metode Taguchi.
Hidayati, A., Riyadi, P.H. dan Rianingsih, L. 2015. Pengaruh Bating Agent dari Ragi Tempe (Rhizopus oligosphorus) terhadap Kualitas Kulit Ikan Nila (Oreochromis niloticus) Samak. Jurnal Saintek Perikanan. 11(1): 26-33.

Kasim, A. 2013. Tanin Gambir Baik untuk Penyamakan Kulit.

Teknologi Pertanian Universitas Andalas, Padang.

Kasim, A., Novia, D., Mutiar S., dan Efendi, A. 2014. Diminishing Chromium Use on Combined Chromium-Gambier Tanning Process Upon the Characteristics of Tanned Leather. Media Peternakan. 37(1): 24-29.

Mahmudi. 2013. Optimalisasi Proses Retaining dan Fatliquoring pada Penyamakan Kulit Bahan Baku Jaket dengan Samak Nabati.

Parmawati, E. 2017. Penentuan Parameter Proses Produksi Genteng Pres Yang Optimal Untuk Meningkatkan Kekuatan Lentur Menggunakan Metode Taguchi, Studi kasus di perusahaan genteng Maryono, Godean, Sleman. Universitas Pembangunan Nasional "Veteran “ Yogyakarta.

Rahayu S., RLM. Satrio A.W. dan Titik A.2015.Pengaruh Natrium Sulfida pada proses pengapuran terhadap uji fisik kulit samak ikan buntal (Arothon reticularis). Jurnal Politeknik ATK Yogyakarta.

Soejanto, I. 2009. Desain Eksperimen dengan Metode Taguchi. Graha Ilmu, Yogyakarta.

Sarkar. 1944. Theory And Practice Of Leather Manufacture.Published by the author 4, second avenue research institute madras.

Fakultas teknik industry jurusan teknik mesin. Universitas Kristen Petra.

Yohanes, A. 2015. Setting Parameter Mesin Ring Spinning Untuk Meningkatkan Kekuatan Tarik Benang PE 30/1 dengan Menggunakan Metode Taguchi. Dinamika Teknik 9(1): 28-37. 